\title{
Analysis of the possibilities for using shale gas to supply gas appliances based on the comparative assessment of gas
}

\begin{abstract}
The article presents a preliminary analysis of the possibility of supplying gas appliances, certified for the gas group E according to EN 437, with the gases obtained from Polish shale. Due to the still small amount of drilling in Poland, data from exploited US shale gas sources from there were used. Comparative assessment indicates the potential for development of Polish shale gases for appliances category $2 \mathrm{E}$ after minor or major modifications involving separating higher hydrocarbons.
\end{abstract}

Key words: shale gas, gas appliances, gas combustion.

\section{Analiza możliwości użytkowania gazów z formacji łupkowych w urządzeniach gazowych w oparciu o ocenę porównawczą gazów}

W artykule przedstawiono wstępną analizę możliwości zasilania urządzeń gazowych certyfikowanych dla gazu grupy E według EN 437 gazem uzyskiwanym z polskich formacji łupkowych. Ze względu na niewielką jeszcze ilość odwiertów w Polsce wykorzystano dane amerykańskie z eksploatowanych tam źródeł gazów z łupków. Ocena porównawcza wskazuje na możliwość zagospodarowania polskich gazów dla urządzeń kategorii 2E po mniejszych lub większych modyfikacjach polegających na odseparowaniu wyższych węglowodorów.

Słowa kluczowe: gaz z formacji łupkowych, urządzenia gazowe, spalanie gazu.

\section{Introduction}

One of the problems to which attention should be paid within projects related to the acquisition of natural gas from shale formations is the problem of the quality of this gas, as related to the possibility of combustion in gas appliances currently in use. This is not a new problem, because, as it is known, in Poland, natural gases are characterised by various configurations of compositions of the basic ingredients, such as methane and nitrogen, supplemented with further hydrocarbons and non-flammable gases, present in low, or even trace, concentrations. Currently, Polish Standards distinguish three subgroups of natural gases: E, Lw, Ls and, until 2011, the Standards also included Lm and Ln gases. In general, it can be said that, in Poland, natural gases exploited from classic fields are within the Wobbe index range from $25 \mathrm{MJ} / \mathrm{m}^{3}$ to $57 \mathrm{MJ} / \mathrm{m}^{3}\left(1013.25 \mathrm{mbar}, 15^{\circ} \mathrm{C}\right.$ and $\left.15^{\circ} \mathrm{C}\right)$. It is hard to evaluate what will be the target quality of the gas from Polish shale formations, which is why this article is based on data published in the United States, where exploitation of shale gas has already reached a very advanced market level. Polish and comparable US gases were subjected to an analysis of their suitability for the supply of equipment covered by Directive 2009/142/EC relating to appliances burning gaseous fuels by comparing them with gases for the EN 437 harmonized standard tests and the above directive. 


\section{Characteristics of the main shale gas fields in the US}

The article by Keith Bulin and others [1] describes six major shale gas fields: Barnett, Marcellus, Fayetteville, New Albany, Antrim and Haynesville. Analysing the parameters of these fields and the composition of the gas exploited from them may be helpful in assessing the gases to be exploited from Polish fields. For better readability, the data presented below were converted into units to which we are accustomed in Poland.

\section{The Barnett field}

The Barnett Field is located in Texas, at a depth of $1980 \mathrm{~m}$ to $2896 \mathrm{~m}$. The main operators are: Chesapeake Energy, Devon, EOG Resources and the average gas exploitation in 2008 ranged from $590 \mathrm{~m}^{3} / \mathrm{h}$ to $4720 \mathrm{~m}^{3} / \mathrm{h}$.

The gas composition adapted from [2] is as follows:

\begin{tabular}{|c|c|c|c|c|c|}
\hline $\begin{array}{c}\text { Field } \\
\text { source }\end{array}$ & $\mathrm{C}_{1}^{1,2}$ & $\mathrm{C}_{2}$ & $\mathrm{C}_{3}$ & $\mathrm{CO}_{2}$ & $\mathrm{~N}_{2}$ \\
\hline 1 & 80.3 & 8.1 & 2.3 & 1.4 & 7.9 \\
\hline 2 & 81.2 & 11.8 & 5.2 & 0.3 & 1.5 \\
\hline 3 & 91.8 & 4.4 & 0.4 & 2.3 & 1.1 \\
\hline 4 & 93.7 & 2.6 & 0.0 & 2.7 & 1.0 \\
\hline Average & 86.75 & 6.725 & 1.975 & 1.675 & 2.875 \\
\hline
\end{tabular}

Gas parameters calculated for the above compositions are shown below:

\begin{tabular}{|l|c|c|c|}
\hline Parameter & $\begin{array}{c}\text { The heat of } \\
\text { combustion } H_{s} \\
{\left[\mathrm{MJ} / \mathrm{m}^{3}\right]}\end{array}$ & $\begin{array}{c}\text { Relative } \\
\text { density } d \\
{[-]}\end{array}$ & $\begin{array}{c}\text { Wobbe index } W_{s} \\
{\left[\mathrm{MJ} / \mathrm{m}^{3}\right]}\end{array}$ \\
\hline Source 1 & 37.895 & 0.656 & 46.782 \\
\hline Source 2 & 43.457 & 0.662 & 53.392 \\
\hline Source 3 & 37.975 & 0.603 & 48.899 \\
\hline Source 4 & 37.120 & 0.595 & 48.103 \\
\hline Average & 39.112 & 0.629 & 49.303 \\
\hline
\end{tabular}

\section{The Marcellus field}

The Marcellus field is located in the north-eastern USA, extending through the states of Pennsylvania, Ohio and West Virginia at a depth of $610 \mathrm{~m}$ to $2438 \mathrm{~m}$. The field was one of enormous potential, initial drill holes showed gas flow range equal to the one in the case of the Barnett field, i.e. $590 \mathrm{~m}^{3} / \mathrm{h}$ to $4720 \mathrm{~m}^{3} / \mathrm{h}$. The potential of this field can be evidenced by the fact that its operator, Southwestern Energy, reached the level of gas production equal to $487286 \mathrm{~m}^{3} / \mathrm{h}$ in 2013 and the total exploitation from the Marcellus field in March 2014 was $17108115 \mathrm{~m}^{3} / \mathrm{h}$ and it is predicted that the field will produce $25 \%$ of the natural gas consumed in the United States in 2015 [6].

The gas composition based on [1] is as follows:

\begin{tabular}{|c|c|c|c|c|c|}
\hline Source & $\mathrm{C}_{1}$ & $\mathrm{C}_{2}$ & $\mathrm{C}_{3}$ & $\mathrm{CO}_{2}$ & $\mathrm{~N}_{2}$ \\
\hline 1 & 79.4 & 16.1 & 4.0 & 0.1 & 0.4 \\
\hline 2 & 82.1 & 14.0 & 3.5 & 0.1 & 0.3 \\
\hline 3 & 83.8 & 12.0 & 3.0 & 0.9 & 0.3 \\
\hline 4 & 95.5 & 3.0 & 1.0 & 0.3 & 0.2 \\
\hline Average & 85.2 & 11.275 & 2.875 & 0.35 & 0.3 \\
\hline
\end{tabular}

Wobbe indices calculated on the basis of the composition indicate that, in addition to its enormous potential, the mining field is characterized by a very stable parameter responsible for the stability of the burner heat load, the Wobbe index.

\begin{tabular}{|c|c|c|c|}
\hline Parameter & $\begin{array}{c}\text { The heat of } \\
\text { combustion } H_{s} \\
{\left[\mathrm{MJ} / \mathrm{m}^{3}\right]}\end{array}$ & $\begin{array}{c}\text { Relative } \\
\text { density } d \\
{[-]}\end{array}$ & $\begin{array}{c}\text { Wobbe index } W_{s} \\
{\left[\mathrm{MJ} / \mathrm{m}^{3}\right]}\end{array}$ \\
\hline Source 1 & 44.473 & 0.661 & 54.701 \\
\hline Source 2 & 43.626 & 0.647 & 54.223 \\
\hline Source 3 & 42.467 & 0.642 & 52.994 \\
\hline Source 4 & 39.021 & 0.581 & 51.214 \\
\hline Average & 42.397 & 0.633 & 53.298 \\
\hline
\end{tabular}

\section{The Fayetteville field}

The Fayetteville field is an unconventional gas field with a thickness from $15 \mathrm{~m}$ to $165 \mathrm{~m}$, stretching along Arkansas, being relatively shallow, from $460 \mathrm{~m}$ to $1980 \mathrm{~m}$. The initial exploitation of $1415 \mathrm{~m}^{3} / \mathrm{h}$ to $4840 \mathrm{~m}^{3} / \mathrm{h}$ increased quickly in consecutive years and, in 2005, production from the field amounted to 67881 thousand $\mathrm{m}^{3}, 14.7$ million $\mathrm{m}^{3}$ was the amount sold in 2009 and it was already 29 million $\mathrm{m}^{3}$ of gas in 2013 [5].

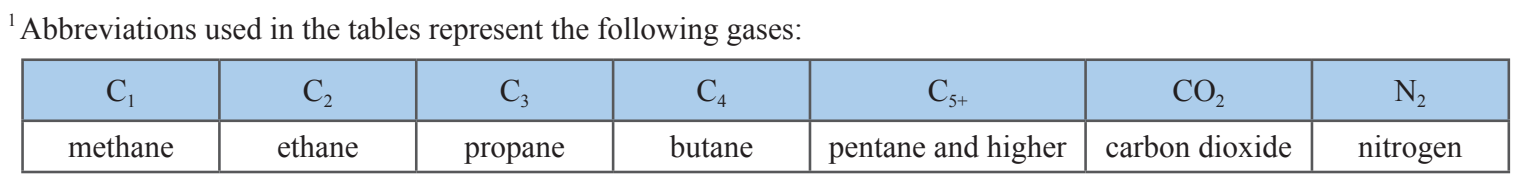

${ }^{2}$ Gas compositions represent percent volumetric compositions. 
The average gas composition of [1] is as follows:

\begin{tabular}{|c|c|c|c|c|c|}
\hline Source & $\mathrm{C}_{1}$ & $\mathrm{C}_{2}$ & $\mathrm{C}_{3}$ & $\mathrm{CO}_{2}$ & $\mathrm{~N}_{2}$ \\
\hline Average & 97.3 & 1.0 & 0.0 & 1.0 & 0.7 \\
\hline
\end{tabular}

And its gas parameters are as follows:

\begin{tabular}{|c|c|c|c|}
\hline Parameter & $\begin{array}{c}\text { The heat of } \\
\text { combustion } H_{s} \\
{\left[\mathrm{MJ} / \mathrm{m}^{3}\right]}\end{array}$ & $\begin{array}{c}\text { Relative } \\
\text { density } d \\
{[-]}\end{array}$ & $\begin{array}{c}\text { Wobbe index } W_{s} \\
{\left[\mathrm{MJ} / \mathrm{m}^{3}\right]}\end{array}$ \\
\hline Average & 37.421 & 0.572 & 49.501 \\
\hline
\end{tabular}

\section{The New Albany field}

The New Albany field is a gas field with a thickness from $30 \mathrm{~m}$ to $120 \mathrm{~m}$ in Southern Illinois, stretching through the states of Indiana and Kentucky at a small depth, from $150 \mathrm{~m}$ to $1500 \mathrm{~m}$. The field's initial production reached the value of $2360 \mathrm{~m}^{3} / \mathrm{h}$. So far, the field is hardly being exploited (only 8 permits for horizontal drilling were issued in 2012-2013). The gas composition adapted from [4] is as follows:

\begin{tabular}{|c|c|c|c|c|c|}
\hline Source & $\mathrm{C}_{1}$ & $\mathrm{C}_{2}$ & $\mathrm{C}_{3}$ & $\mathrm{CO}_{2}$ & $\mathrm{~N}_{2}$ \\
\hline 1 & 87.7 & 1.7 & 2.5 & 8.1 & 0 \\
\hline 2 & 88.0 & 0.8 & 0.8 & 10.4 & 0 \\
\hline 3 & 91.0 & 1.0 & 0.6 & 7.4 & 0 \\
\hline 4 & 92.8 & 1.0 & 0.6 & 6.6 & 0 \\
\hline Average & 89.875 & 1.125 & 1.125 & 8.125 & 0 \\
\hline
\end{tabular}

and the parameters calculated for the composition are shown below. These parameters indicate that, despite some carbon dioxide content, the gases' Wobbe index is very stable:

\begin{tabular}{|c|c|c|c|}
\hline Parameter & $\begin{array}{c}\text { The heat of } \\
\text { combustion } H_{s} \\
{\left[\mathrm{MJ} / \mathrm{m}^{3}\right]}\end{array}$ & $\begin{array}{c}\text { Relative } \\
\text { density } d \\
{[-]}\end{array}$ & $\begin{array}{c}\text { Wobbe index } W_{s} \\
{\left[\mathrm{MJ} / \mathrm{m}^{3}\right]}\end{array}$ \\
\hline Source 1 & 36.649 & 0.665 & 44.950 \\
\hline Source 1 & 34.541 & 0.666 & 42.310 \\
\hline Source 1 & 35.615 & 0.636 & 44.647 \\
\hline Source 1 & 36.295 & 0.634 & 45.577 \\
\hline Average & 35.775 & 0.650 & 44.359 \\
\hline
\end{tabular}

\section{The Antrim field}

One of the most interesting fields, due to the composition of the gas, is the Atrim field located in Michigan. The uniqueness of the composition of the gas is related to the way the field was formed in the process of the bacterial processing of organic material contained in the shale (a process similar to that of biogas formation). By 2008, 71 billion $\mathrm{m}^{3}$ of gas in total was exploited from 9000 wells.

The gas composition adapted from [3] is as follows:

\begin{tabular}{|c|c|c|c|c|c|}
\hline Source & $\mathrm{C}_{1}$ & $\mathrm{C}_{2}$ & $\mathrm{C}_{3}$ & $\mathrm{CO}_{2}$ & $\mathrm{~N}_{2}$ \\
\hline 1 & 27.5 & 3.5 & 1.0 & 3.0 & 65.0 \\
\hline 2 & 57.3 & 4.9 & 1.9 & 0.0 & 35.9 \\
\hline 3 & 77.5 & 4.0 & 0.9 & 3.3 & 14.3 \\
\hline 4 & 85.6 & 4.3 & 0.4 & 9.0 & 0.7 \\
\hline Average & 61.975 & 4.175 & 1.05 & 3.825 & 28.975 \\
\hline
\end{tabular}

The parameters calculated for this composition are shown below:

\begin{tabular}{|c|c|c|c|}
\hline Parameter & $\begin{array}{c}\text { The heat of } \\
\text { combustion } H_{s} \\
{\left[\mathrm{MJ} / \mathrm{m}^{3}\right]}\end{array}$ & $\begin{array}{c}\text { Relative } \\
\text { density } d \\
{[-]}\end{array}$ & $\begin{array}{c}\text { Wobbe index } W_{s} \\
{\left[\mathrm{MJ} / \mathrm{m}^{3}\right]}\end{array}$ \\
\hline Source 1 & 13.661 & 0.877 & 14.584 \\
\hline Source 2 & 26.707 & 0.742 & 30.999 \\
\hline Source 3 & 32.786 & 0.671 & 40.027 \\
\hline Source 4 & 35.567 & 0.666 & 43.591 \\
\hline Average & 27.180 & 0.739 & 31.616 \\
\hline
\end{tabular}

\section{The Haynesville field}

The last field was the field most similar, due to its depth, to Polish fields. It is the Haynesville field located on the border between northern Louisiana and eastern Texas, at a depth of over 3000 meters. The field's temperature is $177^{\circ} \mathrm{C}$ and the pressure is in the range from 210 to 280 bar. Initial exploitation was at the level of $2950 \mathrm{~m}^{3} / \mathrm{h}$ to $23600 \mathrm{~m}^{3} / \mathrm{h}$ and the gas composition is as follows:

\begin{tabular}{|c|c|c|c|c|c|}
\hline Source & $\mathrm{C}_{1}$ & $\mathrm{C}_{2}$ & $\mathrm{C}_{3}$ & $\mathrm{CO}_{2}$ & $\mathrm{~N}_{2}$ \\
\hline Average & 95 & 0.1 & 0 & 4.8 & 0.1 \\
\hline
\end{tabular}

Gas parameters calculated for the composition are as follow:

\begin{tabular}{|c|c|c|c|}
\hline Parameter & $\begin{array}{c}\text { The heat of } \\
\text { combustion } H_{s} \\
{\left[\mathrm{MJ} / \mathrm{m}^{3}\right]}\end{array}$ & $\begin{array}{c}\text { Relative } \\
\text { density } d \\
{[-]}\end{array}$ & $\begin{array}{c}\text { Wobbe index } W_{s} \\
{\left[\mathrm{MJ} / \mathrm{m}^{3}\right]}\end{array}$ \\
\hline Average & 35.957 & 0.602 & 46.338 \\
\hline
\end{tabular}

\section{Composition of gas from the drill holes in Poland}

The following table provides four compositions of gases from the drill holes in which the presence of gas (and oil) was recorded, with parameters that enable initial analysis of their similarities to the gases in distribution. 


\begin{tabular}{|l|c|c|c|c|c|c|c|}
\hline \multicolumn{1}{|c|}{ Drill hole } & $\mathrm{C}_{1}$ & $\mathrm{C}_{2}$ & $\mathrm{C}_{3}$ & $\mathrm{C}_{4}$ & $\mathrm{C}_{5+}$ & $\mathrm{CO}_{2}$ & $\mathrm{~N}_{2}$ \\
\hline Lubocino-1 & 73.61 & 13.16 & 6.38 & 2.571 & 1.466 & 0.11 & 2.34 \\
\hline Berejów separator & 66.76 & 11.90 & 8.23 & 5.048 & 3.590 & 0.53 & 3.33 \\
\hline Berejów oil degassing & 62.14 & 12.01 & 8.42 & 4.496 & 7.947 & 0.85 & 3.72 \\
\hline Syczyn & 84.25 & 5.97 & 3.33 & 1.460 & 1.066 & 0.15 & 3.57 \\
\hline
\end{tabular}

Energy parameters of these gases are as follows:

\begin{tabular}{|l|c|c|c|}
\hline \multicolumn{1}{|c|}{ Parameter } & $\begin{array}{c}\text { The heat of combustion } H_{s} \\
{\left[\mathrm{MJ} / \mathrm{m}^{3}\right]}\end{array}$ & $\begin{array}{c}\text { Relative density } d \\
{[-]}\end{array}$ & $\begin{array}{c}\text { Wobbe index } W_{s} \\
{\left[\mathrm{MJ} / \mathrm{m}^{3}\right]}\end{array}$ \\
\hline Lubocino-1 & 48.552 & 0.766 & 55.475 \\
\hline Berejów separator & 53.301 & 0.866 & 57.277 \\
\hline Berejów oil degassing & 59.927 & 0.991 & 60.199 \\
\hline Syczyn & 42.647 & 0.678 & 51.793 \\
\hline
\end{tabular}

\section{Parameters of test gases}

To assess the potential uses of the gases described above, the following table presents the characteristics of the test gases used, according to PN-EN 437 [7], during testing gas appliances designed to be supplied with natural gas group E, for which the reference gas - G20 is methane: limit gas G231, represent extreme Wobbe indices which, in the case of the actual group E gases, are in the range of $40.9 \mathrm{MJ} / \mathrm{m}^{3}$ to $54.7 \mathrm{MJ} / \mathrm{m}^{3}$. While the flashback limit gas - G222, shows potential content of unsaturated hydrocarbons with their burning rate much higher than the rate of the combustion of methane

\begin{tabular}{|c|l|c|c|c|c|c|c|c|}
\hline $\begin{array}{c}\text { Gas family } \\
\text { and group }\end{array}$ & Test gases & Designation & $\begin{array}{c}\text { Volumetric } \\
\text { composition } \\
{[\%]}\end{array}$ & $\begin{array}{c}W_{i} \\
{\left[\mathrm{MJ} / \mathrm{m}^{3}\right]}\end{array}$ & $\begin{array}{c}H_{i} \\
{\left[\mathrm{MJ} / \mathrm{m}^{3}\right]}\end{array}$ & $\begin{array}{c}W_{s} \\
{\left[\mathrm{MJ} / \mathrm{m}^{3}\right]}\end{array}$ & $\begin{array}{c}H_{s} \\
{\left[\mathrm{MJ} / \mathrm{m}^{3}\right]}\end{array}$ & $d$ \\
\hline \multirow{5}{*}{ Group E } & Reference gas & $\mathrm{G} 20$ & $\mathrm{CH}_{4}=100$ & 45.67 & 34.02 & 50.72 & 37.78 & 0.555 \\
\cline { 2 - 10 } & $\begin{array}{l}\text { Yellow tipping and incom- } \\
\text { plete combustion limit gas }\end{array}$ & $\mathrm{G} 21$ & $\begin{array}{c}\mathrm{CH}_{4}=87 \\
\mathrm{C}_{3} \mathrm{H}_{8}=13\end{array}$ & 49.60 & 41.01 & 54.76 & 45.28 & 0.684 \\
\cline { 2 - 10 } & Flashback limit gas & $\mathrm{G} 222$ & $\begin{array}{c}\mathrm{CH}_{4}=77 \\
\mathrm{H}_{2}=23\end{array}$ & 42.87 & 28.53 & 47.87 & 31.86 & 0.443 \\
\cline { 2 - 9 } & Flame lift-off limit gas & $\mathrm{G} 231$ & $\begin{array}{c}\mathrm{CH}_{4}=85 \\
\mathrm{~N}_{2}=15\end{array}$ & 36.82 & 28.91 & 40.90 & 32.11 & 0.617 \\
\hline
\end{tabular}

As can be seen, the gases in the above table represent the limit test gases situations that may arise during the operation of the distributed gases. Limit gases: the yellow tipping and incomplete combustion limit gas - G21 and the flame lift-off in the gas supplied to the device, thus contributing to the flame flashback onto the burner nozzle. Test gases, as referred to in the above-mentioned standard, enable obtaining similar results in the case of the same types of devices in several laboratories.

\section{Assessment of the suitability of shale gases for use}

Analysing the above-mentioned compositions of shale gases, both the American and Polish ones, at first glance relatively large differences in gas composition can be noted, depending on the location of the field. The comparative analysis conducted enables the exclusion of the Antrim field. Due to its depth and the resulting temperature and pressure, it is unlikely for Polish fields to exhibit a similar process of methane production. Considering the Marcellus and Barnett fields, similarities in the content of ethane and propane can be seen when comparing the gases with Polish gases. These fields produce very high-energy gases, at the upper limit of the Wobbe index for group E. Basing on the composition of methane and ethane in these gases, it can be assumed that the gases are very similar to the gases from the Lubocin and Barejów drill holes. They are relatively better degasolined than Polish gases, apparently containing 
relatively large amounts of $\mathrm{C}_{5^{+}}$hydrocarbons (this group includes hydrocarbons up to $\mathrm{C}_{11}$ ).

The above-mentioned American fields, excluding the Antrim field, produce gases within the proper range of the Wobbe index, as recognized in the EN 437 standard for group E. Whereas in the case of the Polish fields, only the Syczyn gas can be directly consumed in the I2E gas appliances. Other gases need to be adjusted, e.g. by removing of excess higher hydrocarbons, starting with butane. It is interesting to compare the gases from the Barnett and Marcellus fields with hypothetical compositions of the gases from the Lubocino-1 and Syczyn fields, as obtained when modelling separation of butane and higher hydrocarbons (all of them are then within the range for gas $\mathrm{E}$ ).

\begin{tabular}{|l|c|c|c|c|c|c|}
\hline Parameter & $\mathrm{C}_{1}$ & $\mathrm{C}_{2}$ & $\mathrm{C}_{3}$ & $\mathrm{CO}_{2}$ & $\mathrm{~N}_{2}$ & $\begin{array}{c}\text { Wobbe } \\
\text { index }\end{array}$ \\
\hline Barnett & 86.75 & 6.725 & 1.975 & 1.675 & 2.875 & 49.303 \\
\hline Marcellus & 85.20 & 11.275 & 2.875 & 0.350 & 0.300 & 53.298 \\
\hline Lubocino-1 & 76.71 & 14.170 & 6.650 & 0.115 & 2.440 & 53.876 \\
\hline Syczyn & 86.43 & 5.990 & 3.430 & 0.155 & 3.680 & 50.352 \\
\hline
\end{tabular}

\section{Summary}

The above analysis refers only to Polish gas exploited from just three drill holes. However, if the trend of gas compositions exploited from new wells remained at this level, there should be no problem with using the gases. The example of American gases shows that the trend is highly probable.

Please cite as: Nafta-Gaz 2015, no. 11, pp. 924-928, DOI: 10.18668/NG2015.11.16

Article contributed to the Editor 3.07.2015. Approved for publication 24.09.2015.

The article is the result of research conducted in connection with a project: Development of optimum concepts for unconventional deposits management, considering environmental and social aspects, co-funded by the National Centre for Research and Development as part of the programme BLUE GAS - POLISH SHALE GAS. Contract No. BG1/ResDev/13.

\section{Literature}

[1] e-book: Composition Variety Complicates Processing Plans for US Shale Gas, by: Keith Bullin PhD, Peter Krouskop PhD, Bryan Research and Engineering Inc. Bryan, Tex. Based on: Annual Forum, Gas Processors Association, Houston Chapter, Oct. 7, 2008, Houston.

[2] Hill R. J., Jarvie D. M., Zumberge J., Henry M., Pollastro R. M.: Oil and gas geochemistry and petroleum systems of the Fort Worth Basin. AAPG Bulletin 2007, vol. 91, no. 4, pp. 445-473.

[3] Martini A. M., Walter L. M., Ku T. C. W., Budai J. M., McIntosh J. C., Schoell M.: Microbial Production and modification of gases in sedimentary basins: A geochemical case study from a Devonian shale gas play, Michigan basin. AAPG Bulletin 2003, vol. 87, no. 8, pp. 1355-1375.

[4] Martini A. M., Walter L. M., McIntosh J. C.: Identification of microbial and thermogenic gas components from Upper Devonian black shale cores, Illinois and Michigan basins. AAPG Bulletin 2008, vol. 92, no. 3, pp. 327-339.

[5] State of Arkansas Oil and Gas Commission, June 2014.

[6] UOGR 10 June 2014: Marcellus continues to defy expectations, driving US gas production ever higher.

\section{Legal and normative acts}

[7] PN-EN 437+A1:2012 Gazy do badań - Ciśnienia próbne - Kategorie urządzeń.

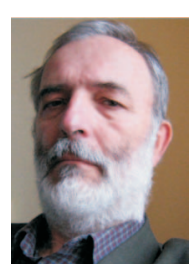

Dr. Eng. Zdzisław Gebhardt PhD. Assistant Professor

Head of the Fuels Usage Department Oil and Gas Institute - National Research Institute ul. Lubicz 25 A 31-503 Kraków E-mail: zdzislaw.gebhardt@inig.pl 